\title{
Posterior reversible leukoencephalopathy syndrome associated with acute postinfectious glomerulonephritis: systematic review
}

\author{
Corinne Orlando ${ }^{1}$ - Gregorio P. Milani ${ }^{2,3}$. Giacomo D. Simonetti ${ }^{4,5}$ - Barbara Goeggel Simonetti ${ }^{4,5,6}$. \\ Sebastiano A. G. Lava $^{7} \cdot$ Rolf Wyttenbach $^{5,8,9} \cdot$ Mario G. Bianchetti $^{1,5}$ (1) Marirosa Cristallo Lacalamita $^{8}$
}

Received: 29 March 2021 / Revised: 9 July 2021 / Accepted: 9 July 2021 / Published online: 21 September 2021

(c) The Author(s) 2021, corrected publication 2022

\begin{abstract}
Background Kidney diseases are a recognized cause of posterior reversible leukoencephalopathy syndrome, usually abbreviated as PRES. The purpose of this review was to systematically address the association between acute postinfectious glomerulonephritis and PRES.

Methods We performed a systematic review of the literature on acute postinfectious glomerulonephritis associated with PRES. The principles recommended by the Economic and Social Research Council guidance on the conduct of narrative synthesis and on the Preferred Reporting Items for Systematic Reviews and Meta-analyses were used. Databases searched included Excerpta Medica, US National Library of Medicine, and Web of Science.

Results For the final analysis, we evaluated 47 reports describing 52 cases ( 32 males and 20 females). Fifty patients were $\leq 18$ years of age. Blood pressure was classified as follows: normal-elevated $(n=3)$, stage 1 hypertension $(n=3)$, stage 2 hypertension $(n=5)$, and severe hypertension $(n=41)$. Acute kidney injury was classified as stage 1 in 32 , stage 2 in 16 , and stage 3 in four cases. Neuroimaging studies disclosed a classic posterior PRES pattern in 28 cases, a diffuse PRES pattern in 23 cases, and a brainstem-cerebellum PRES pattern in the remaining case. Antihypertensive drugs were prescribed in all cases and antiepileptic drugs in cases presenting with seizures. A resolution of clinical findings and neuroimaging lesions was documented in all cases with information about follow-up.

Conclusions The main factor associated with PRES in acute postinfectious glomerulonephritis is severe hypertension. Prompt clinical suspicion, rapid evaluation, and management of hypertension are crucial.
\end{abstract}

Keywords Acute brain capillary leak syndrome $\cdot$ Acute postinfectious glomerulonephritis $\cdot$ Acute poststreptococcal glomerulonephritis $\cdot$ Hypertensive encephalopathy $\cdot$ Posterior reversible leukoencephalopathy syndrome

Mario G. Bianchetti

mario.bianchetti@usi.ch

1 Family Medicine Institute, Faculty of Biomedical Sciences, Università Della Svizzera Italiana, Lugano, Switzerland

2 Pediatric Unit, Fondazione IRCCS Ca' Granda Ospedale Maggiore Policlinico, Milan, Italy

3 Department of Clinical Sciences and Community Health, Università Degli Studi Di Milano, Milan, Italy

4 Pediatric Institute of Southern Switzerland EOC, Ospedale San Giovanni, Bellinzona, Switzerland

5 Faculty of Biomedical Sciences, Università Della Svizzera Italiana, Lugano, Switzerland
6 Department of Neurology, University Hospital Bern, University of Bern, Bern, Switzerland

7 Pediatric Cardiology Unit, Department of Pediatrics, Centre Hospitalier Universitaire Vaudois and University of Lausanne, Lausanne, Switzerland

8 Imaging Institute of Southern Switzerland EOC, Bellinzona, Switzerland

9 Department of Diagnostic, Interventional and Pediatric Radiology (DIPR), Inselspital, Bern University Hospital, University of Bern, Bern, Switzerland 


\section{Introduction}

Posterior reversible leukoencephalopathy syndrome, usually abbreviated as PRES, is a rather uncommon condition, whose diagnosis relies both on clinical and imaging features $[1,2]$. The clinical presentation includes headache or nausea; altered mental status; seizures; visual perception abnormalities; and, less frequently, further focal neurologic signs. Neuroimaging studies demonstrate a characteristically reversible vasogenic edema that generally involves the subcortical white matter in the posterior cerebral regions [2]. A variety of conditions have been implicated as causes of PRES, including among others severe arterial hypertension and both acute and chronic kidney diseases [2]. Some drugs have also been deemed to cause PRES [3].

Stimulated by our past experience $[4,5]$, we report here the first systematic literature review on PRES in postinfectious (poststreptococcal) glomerulonephritis, the prototypical and most widely known acute glomerulonephritis syndrome $[6,7]$. The objectives were to document features, associated factors, neuroimaging data, and clinical course.

\section{Methods}

\section{Literature search strategy}

For this analysis, we followed the Preferred Reporting Items for Systematic Reviews and Meta-Analyses guidelines and searched up to November 2020 in the US National Library of Medicine, Excerpta Medica, and Web of Sciences databases [8]. We carried out a structured literature search without date limitation using the Medical Subject Headings terms "poststreptococcal glomerulonephritis" OR "postinfectious glomerulonephritis" AND “encephalopathy” OR "posterior reversible encephalopathy syndrome" OR "posterior reversible leukoencephalopathy syndrome" OR "PRES." Articles in languages other than Spanish, Portuguese, Italian, German, French, English, or Dutch were not included. The literature search was carried out by two investigators (CO, MGB), who independently screened the title and abstract of all reports in a non-blinded fashion to include pertinent reports. Discrepancies in study identification were resolved by consensus. Subsequently, full-text publications were reviewed to decide whether the presented case fit the eligibility criteria of the review. Personal files and the bibliography of each identified report were also screened for further references. Institutional Review Board approval was not required for this literature review.

\section{Selection criteria-definitions-data extraction}

Of interest were subjects without any pre-existing kidney or cerebral disease presenting with acute postinfectious glomerulonephritis and PRES, whose history had been published in full-length articles or letters. Prospectively defined criteria were used to confirm or infirm the diagnosis of acute poststreptococcal glomerulonephritis, arterial hypertension, and PRES made in the original articles.

The diagnosis of postinfectious glomerulonephritis was retained in patients with acute onset of hematuria and proteinuria associated with (a) $\mathrm{C}_{3}$ hypocomplementemia returning to normal within 16 weeks, (b) increasing antistreptoscorecoccal antibodies, or (c) distinctive kidney biopsy findings [6, 7]. The KDIGO criteria [9] were used to classify acute kidney damage as stage 1 (increase in creatinine to $1.5-1.9$ times baseline or increase by $\geq 27 \mu \mathrm{mol} / \mathrm{l}$ above the upper limit of normal for age), stage 2 (increase in creatinine to 2.0-2.9 times baseline), or stage 3 (increase in creatinine to $\geq 3.0$ times baseline, increase in creatinine by $\geq 354 \mu \mathrm{mol} / 1$, or initiation of dialysis).

The highest recorded blood pressure value at presentation was used to categorize hypertension as stage 1 (subjects 1 to $<13$ years of age with blood pressure readings $\geq 95$ th percentile to 95 th percentile $+12 \mathrm{~mm} \mathrm{Hg}$; subjects $\geq 13$ years with readings between 130/80 and 139/89 $\mathrm{mm} \mathrm{Hg}$ ); stage 2 (subjects 1 to $<13$ years of age with readings 95 th percentile $+12 \mathrm{~mm} \mathrm{Hg}$ to 95 th percentile $+30 \mathrm{~mm} \mathrm{Hg}$; subjects aged $\geq 13$ years with reading $\geq 140 / 90$ to $179 / 119 \mathrm{~mm} \mathrm{Hg}$ ); or severe (subjects 1 to $<13$ years of age with readings $\geq 95$ th percentile $+>30 \mathrm{~mm} \mathrm{Hg}$; subjects aged $\geq 13$ years with readings $>180 / 120 \mathrm{~mm} \mathrm{Hg}$ ). Blood pressure was categorized as normal in the remaining cases [10, 11].

The diagnosis of PRES was made on the basis of both an acute onset of at least one of five neurologic features ((1) headache or nausea; (2) altered mental status; (3) seizures; (4) visual perception abnormalities; (5) further focal neurologic signs) and distinctive neuroimaging findings [12, 13].

Neuroimaging data were classified based on lesion location patterns and severity. Lesion location patterns were categorized based on cerebral edema distribution (Fig. 1) as posterior, anterior, diffuse, brainstem-cerebellum, or basal ganglia [12]. Lesion severity was categorized as mild, moderate, or severe according to the vasogenic edema extent, the involvement of deep structures (cerebellum, brainstem, or basal ganglia), and the presence of parenchymal hemorrhage [13].

In addition to demographics, from each reported case, we evaluated the following clinical information: non-renal and non-cerebral pre-existing conditions, initial presentation, the abovementioned neurologic findings, blood pressure values, laboratory data (including creatinine among others), patient 
Fig. 1 Posterior reversible leukoencephalopathy syndrome. Sketch depicting the five lesion location patterns of white matter edema (blue): posterior, anterior, diffuse, brainstemcerebellum, and basal ganglia
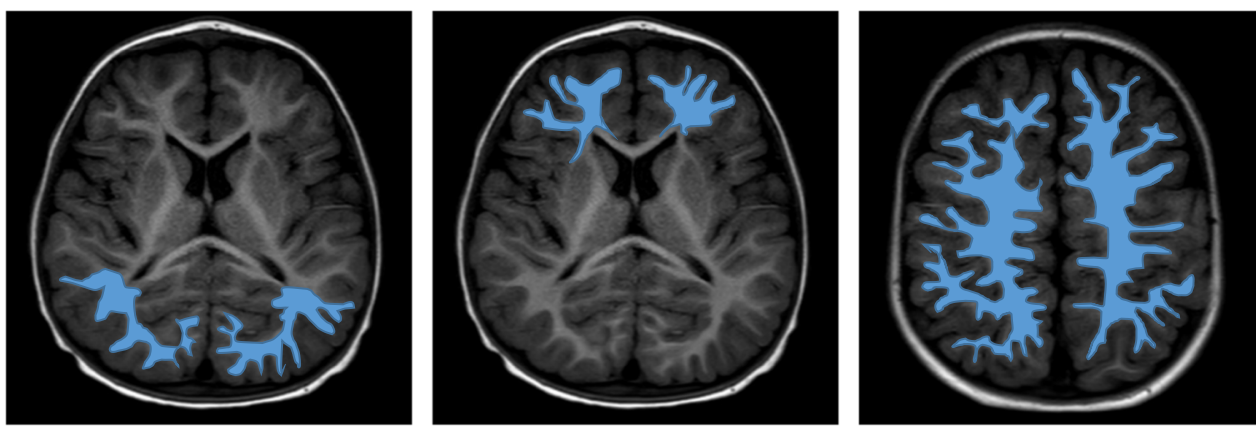

posterior

anterior

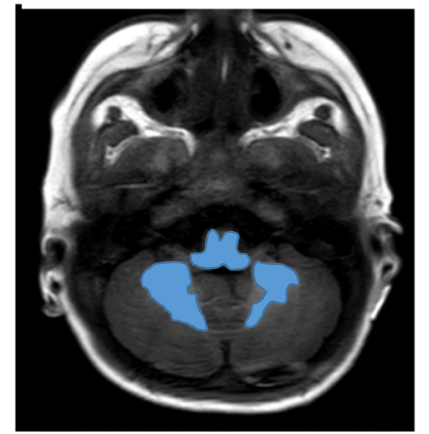

brainstem-cerebellum

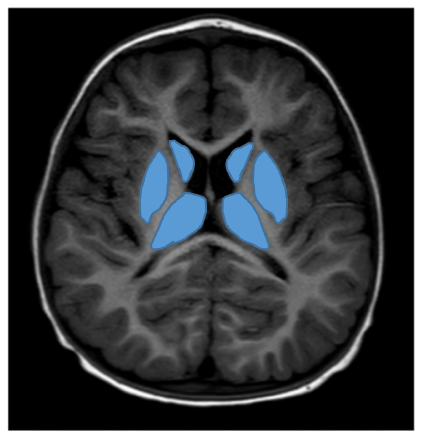

basal ganglia management, and the disease course. The following neuroimaging data were weighted: brain scans performed with magnetic resonance imaging (MRI) rather than computed tomography (CT), accuracy of technical report, description of distribution patterns, figure and caption preciseness.

Two authors graded subjectively in consensus the comprehensiveness in reporting the clinical (CO, MGB) and the neuroimaging data (RW, MCL) as satisfactory or good.

\section{Analysis}

A pilot-tested form was used for data extraction and recording. Results are given as median and interquartile range or as frequency, as appropriate. The Wilcoxon rank-sum test was used to compare continuous variables and the Fisher exact test to compare dichotomous variables. Significance was assigned at $P<0.05$.

\section{Results}

\section{Search outputs}

The study flowchart is shown in Fig. 2. For the final analysis, we retained 47 scientific reports [4, 5, 14-58] detailing 52 original cases published since 1993: 22 from Asia (Turkey, $n=8$; India, $n=7$; Japan, $n=3$; Pakistan, $n=1$; Saudi Arabia, $n=1$; Sri Lanka, $n=1$, Taiwan, $n=1$ ), nine from Europe (Germany, $n=2$; Italy, $n=2$; Belgium, $n=1$; Greece, $n=1$; Netherlands, $n=1$; Spain, $n=1$; Switzerland, $n=1$ ), eight from North America (USA, $n=7$; Canada, $n=1$ ), six from South America (Argentina, $n=2$; Brazil, $n=1$; Colombia, $n=1$; Trinidad, $n=1$; Uruguay, $n=1$ ), and two from Africa (Morocco, $n=1$; Tunisia, $n=1$ ). Thirty-eight articles were published in English, five in Spanish, two in French, one in Dutch, and one in German.

The comprehensiveness in reporting clinical data was good in 44 and satisfactory in eight cases, that is, reporting neuroimaging data was good in 31 and satisfactory in 21 cases.

\section{Clinical and laboratory data at presentation}

Information on the 52 patients - 50 children and 2 adults - appears in Table 1. The initial clinical presentation was neurologic in three quarters of the cases. Seizures, headache, nausea, altered mental status, and visual disturbances were, in decreasing order of frequency, the main neurologic features. Arterial hypertension was severe in approximately $80 \%$ of cases. Stage 3 acute kidney injury was noted in less than $10 \%$ of cases.

The following neuroimaging techniques were used for the evaluation of disease onset in the 52 patients: MRI $(n=24)$; CT followed by MRI $(n=22)$; CT $(n=6)$. A CT 


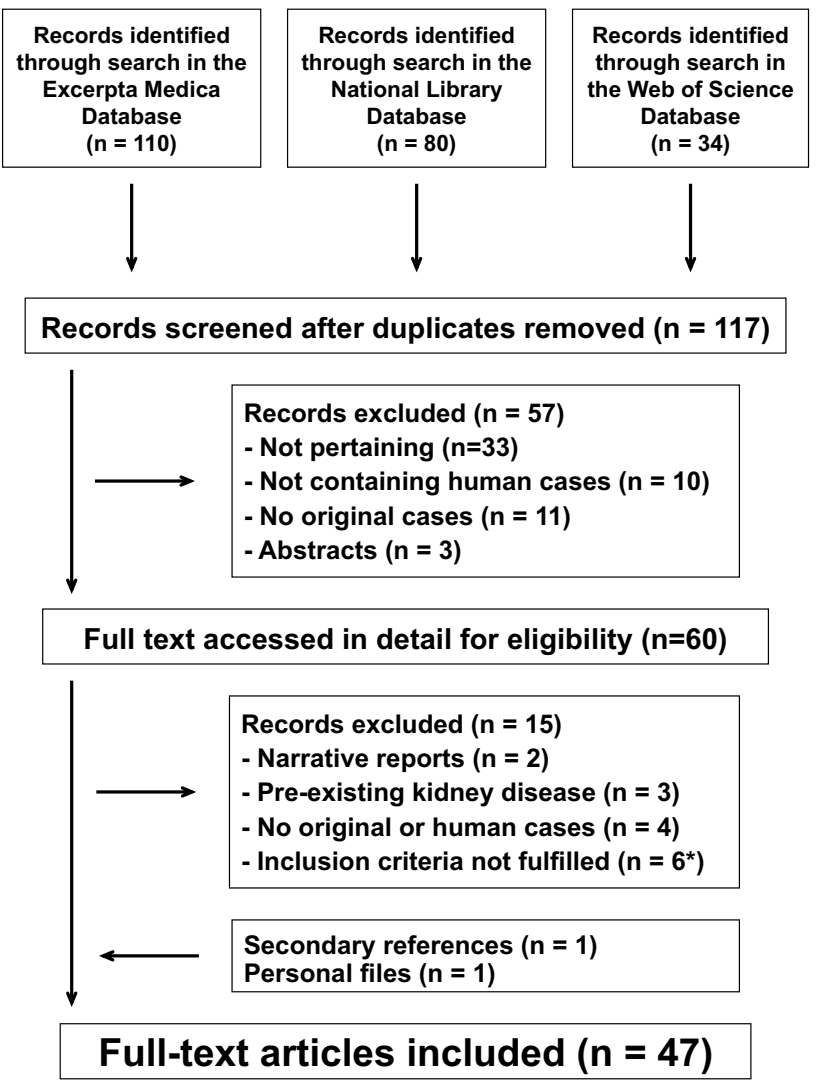

Fig. 2 Posterior reversible leukoencephalopathy syndrome associated with acute postinfectious glomerulonephritis. Flowchart of the literature search process (*poor-quality neuroimaging studies, $n=5$; poorly documented kidney disease, $n=1$ )

with a contrast agent was obtained in four cases. An invasive digital subtraction angiography study was performed in two cases $[17,27]$. The following magnetic resonance imaging sequences were used in the 46 patients: T2WI and/ or FLAIR, $n=46$; DWI with ADC, $n=20$; TOF, $n=3$; T1 $\mathrm{C}+, n=7$. A posterior pattern of distribution was detected in 28 cases, a diffuse pattern in 23 cases, and a brainstemcerebellum-predominant pattern in the remaining case [14]. No patient was found to have an anterior or a basal ganglia pattern. The neuroimaging severity score was mild in about $95 \%$ of cases.

Further neuroimaging abnormalities were observed in three cases $[32,33,56]$, as shown in Table 2 . Two of the mentioned children were concurrently affected by sickle cell anemia $[33,56]$. The 9-year-old girl reported by Hanafy [56] concomitantly presented with an acute postinfectious glomerulonephritis and a vaso-occlusive crisis. No features consistent with a vaso-occlusive crisis were noted in the 10-year-old boy reported by Pashankar [33].

No significant statistical difference was noted between patients with a posterior pattern and patients with a diffuse pattern with respect to demographics, initial clinical presentation, neurologic features (including visual disturbances), blood pressure, kidney injury, and neuroimaging severity score (Table 1 ).

Patients with severe arterial hypertension and patients with normal or non-severe hypertension did not significantly differ with respect to gender, age, neurologic features, severity of acute kidney injury, and edema distribution pattern (Table 3). Antihypertensive drugs were more frequently prescribed in the group of patients with severe hypertension.

\section{Management course}

Drug management is depicted in Table 1. Noticing that antihypertensive and antiepileptic drug therapy was administered in a heterogeneous manner, was frequently adjusted, and was often poorly documented in the articles, no attempt was made to condense these data. Eleven patients received systemic corticosteroids.

A full resolution of clinical findings including among others the neurologic examination, blood pressure, urinalysis, and kidney function was documented within 3 to 16 weeks in 47 cases, including the three children found to have either an ischemic or a hemorrhagic brain lesion [32, 33, 56].

Follow-up neuroimaging studies were performed in 38 cases [2-8] 4 weeks after disease onset: MRI in 33 cases (including one patient revalued also by a digital subtraction angiography) and CT in 5 cases. A complete resolution of the lesions was noted in all of them, including the aforementioned three cases complicated by ischemic or hemorrhagic lesions $[32,33,56]$.

\section{Discussion}

This is the first systematic review to investigate the association of acute postinfectious glomerulonephritis with PRES. The results indicate that this association predominantly affects, like glomerulonephritis without encephalopathy $[6,7]$, male school-aged children, that it is associated with severe arterial hypertension in four out of five cases and its prognosis is generally favorable.

It has been suggested that severe acute-onset arterial hypertension accounts for most cases of PRES $[1,2]$. In our survey, blood pressure was severely elevated in approximately $80 \%$ of cases, thereby supporting the abovementioned link. The term hypertensive encephalopathy was traditionally used to denote this important form of PRES [2, $59,60]$. Since cerebral blood flow is normally maintained at a constant level by vascular resistance autoregulation, PRES likely occurs in cases with blood pressure beyond the upper autoregulation limit. In this setting, a breakdown of the blood-brain barrier allows for the extravasation of blood products and extracellular vasogenic edema, which mainly 
Table 1 Clinical, laboratory, and imaging data in 52 patients from 7 to 32 years of age with acute poststreptococcal glomerulonephritis associated with posterior reversible leukoencephalopathy syndrome. Data are given as median (with interquartile range) or as relative frequency (with percentage)

\begin{tabular}{|c|c|c|c|c|c|}
\hline & All & Posterior & Diffuse & $\begin{array}{l}\text { Brainstem } \\
\text { cerebellum }\end{array}$ & P-value* \\
\hline$N$ & 52 & 28 & 23 & 1 & \\
\hline Males:females, $N$ & $32: 20$ & $18: 10$ & $14: 9$ & $0: 1$ & $>0.999$ \\
\hline \multicolumn{6}{|l|}{ Age } \\
\hline Years & $11[9-13]$ & $10[9-12]$ & $12[10-14]$ & 9 & 0.121 \\
\hline$\leq 18$ years, $\mathrm{N}(\%)$ & $50(96)$ & $26(93)$ & $23(100)$ & 1 & 0.494 \\
\hline Pre-existing condition, $N(\%)$ & $2 *(4)$ & $0(0)$ & $2 *(9)$ & 0 & 0.492 \\
\hline \multicolumn{6}{|l|}{ Initial presentation } \\
\hline Neurologic, $N(\%)$ & $37(71)$ & $21(75)$ & $16(70)$ & 0 & 0.757 \\
\hline Renal, $N(\%)$ & $13(25)$ & $5(18)$ & $7(30)$ & 1 & 0.336 \\
\hline Neurologic and renal, $N(\%)$ & $2(4)$ & $2(7)$ & $0(0)$ & 0 & 0.495 \\
\hline \multicolumn{6}{|l|}{ Neurologic features } \\
\hline Headache-nausea, $N(\%)$ & $44(85)$ & $25(89)$ & $19(83)$ & 1 & 0.687 \\
\hline Altered mental status, $N(\%)$ & $38(73)$ & $20(71)$ & $18(78)$ & 0 & 0.749 \\
\hline Seizures, $N(\%)$ & $46(88)$ & $23(82)$ & $22(96)$ & 1 & 0.739 \\
\hline Visual abnormalities, $N(\%)$ & $29(56)$ & $17(61)$ & $11(48)$ & 1 & 0.407 \\
\hline Further focal signs, $N(\%)$ & $13(25)$ & $5(18)$ & $8(35)$ & 0 & 0.207 \\
\hline \multicolumn{6}{|l|}{ Blood pressure } \\
\hline Normal-elevated, $N(\%)$ & $3(6)$ & $0(0)$ & $3(13)$ & 0 & 0.085 \\
\hline Stage 1 hypertension, $N(\%)$ & $3(6)$ & $0(0)$ & $2(9)$ & 1 & 0.198 \\
\hline Stage 2 hypertension, $N(\%)$ & $5(10)$ & $4(4)$ & $1(4)$ & 0 & 0.362 \\
\hline Severe hypertension, $N(\%)$ & $41(79)$ & $24(86)$ & $17(74)$ & 0 & 0.316 \\
\hline \multicolumn{6}{|l|}{ Acute kidney injury } \\
\hline Stage $1, N(\%)$ & $32(62)$ & $19(68)$ & $13(57)$ & 0 & 0.561 \\
\hline Stage $2, N(\%)$ & $16(31)$ & $8(29)$ & $8(35)$ & 0 & 0.369 \\
\hline Stage $3, N(\%)$ & $4(8)$ & $1(4)$ & $2(9)$ & 1 & 0.583 \\
\hline \multicolumn{6}{|l|}{ Neuroimaging severity score } \\
\hline Mild, $N(\%)$ & $49(94)$ & $28(100)$ & $21(91)$ & 0 & 0.198 \\
\hline Moderate, $N(\%)$ & $2(4)$ & $0(0)$ & $1(4)$ & 1 & 0.451 \\
\hline Severe, $N(\%)$ & $1(2)$ & $0(0)$ & $1(4)$ & 0 & 0.451 \\
\hline \multicolumn{6}{|l|}{ Drug therapy } \\
\hline Antihypertensives, $N(\%)$ & $48(92)$ & $27(96)$ & $21(91)$ & 0 & 0.583 \\
\hline Antiepileptics, $N(\%)$ & $38(73)$ & $19(68)$ & $19(83)$ & 0 & 0.336 \\
\hline Corticosteroids, $N(\%)$ & $11(21)$ & $3(21)$ & $7(13)$ & 1 & 0.154 \\
\hline
\end{tabular}

${ }^{*}$ Posterior versus diffuse

Table 2 Neuroimaging abnormalities other than vasogenic edema in 3 patients with PRES associated with acute poststreptococcal glomerulonephritis $[32,33,56]$

\begin{tabular}{|c|c|c|c|}
\hline Gender & Female [56] & Male [33] & Female [32] \\
\hline Age, years & 9 & 10 & 13 \\
\hline Concomitant condition & Sickle cell disease with vaso-occlusive crisis & $\begin{array}{l}\text { Sickle cell disease without } \\
\text { vaso-occlusive crisis }\end{array}$ & None \\
\hline Neuroimaging PRES pattern & Diffuse & Diffuse & Diffuse \\
\hline Blood pressure & Stage 3 hypertension & Stage 3 hypertension & Normal-elevated \\
\hline Abnormality & $\begin{array}{l}\text { Ischemic lesions involving the cortex of the right } \\
\text { occipito-parietal lobe and the right thalamic region }\end{array}$ & $\begin{array}{l}\text { Right frontal intraparen- } \\
\text { chymal hemorrhage }\end{array}$ & $\begin{array}{l}\text { Supratentorial } \\
\text { subarachnoid } \\
\text { hemorrhage }\end{array}$ \\
\hline
\end{tabular}


Table 3 Characteristics of patients with severe arterial hypertension and patients with normal or non-severe hypertension. Data are presented as median (with interquartile range) or as frequency (with percentage)

\begin{tabular}{|c|c|c|c|}
\hline & \multicolumn{2}{|l|}{ Blood pressure } & \multirow[t]{2}{*}{$P$-value } \\
\hline & $\begin{array}{l}\text { Severe arterial hyper- } \\
\text { tension }\end{array}$ & $\begin{array}{l}\text { Normal or non-severe } \\
\text { hypertension }\end{array}$ & \\
\hline$N$ & 41 & 11 & \\
\hline Males:females, $N$ & $25: 16$ & $7: 4$ & $>0.999$ \\
\hline Age, years & $11[9-13]$ & $12[10-14]$ & 0.208 \\
\hline \multicolumn{4}{|l|}{ Neurologic features } \\
\hline Headache-nausea, $N(\%)$ & $35(85)$ & $9(82)$ & $>0.999$ \\
\hline Altered mental status, $N(\%)$ & $29(71)$ & $9(82)$ & 0.469 \\
\hline Seizures, $N(\%)$ & $37(90)$ & $9(82)$ & 0.595 \\
\hline Visual abnormalities, $N(\%)$ & $22(54)$ & $7(64)$ & 0.735 \\
\hline Further focal signs, $N(\%)$ & $12(29)$ & $1(9.1)$ & 0.253 \\
\hline \multicolumn{4}{|l|}{ Acute kidney injury } \\
\hline Stage $1, N(\%)$ & $25(61)$ & $7(64)$ & $>0.999$ \\
\hline Stage $2, N(\%)$ & $14(34)$ & $2(18)$ & 0.468 \\
\hline Stage $3, N(\%)$ & $2(4.9)$ & $2(18)$ & 0.193 \\
\hline \multicolumn{4}{|l|}{ Edema distribution pattern } \\
\hline Posterior, $N(\%)$ & $24(58)$ & $4(36)$ & 0.308 \\
\hline Diffuse, $N(\%)$ & $17(41)$ & $6(55)$ & 0.507 \\
\hline Brainstem-cerebellum, $N(\%)$ & 0 & $1(9.1)$ & 0.212 \\
\hline \multicolumn{4}{|l|}{ Drug therapy } \\
\hline Antihypertensives, $N(\%)$ & $41(100)$ & $7(64)$ & $<0.005$ \\
\hline Antiepileptics, $N(\%)$ & $30(73)$ & $8(73)$ & $>0.999$ \\
\hline Corticosteroids, $N(\%)$ & $9(22)$ & $2(18)$ & $>0.999$ \\
\hline
\end{tabular}

affects the white matter via leakage of fluid from capillaries $[59,60]$. Blood pressure was normal or not severely elevated in approximately $20 \%$ of cases included in this analysis [59, 60]. The present figures differ from those observed in immunoglobulin A vasculitis [61]. In the latter condition, PRES was associated with severe hypertension in no more than every third case, suggesting a crucial pathogenic role for the cerebral vasculitis in the majority of cases [61]. It is therefore tempting to assume that, like in immunoglobulin A vasculitis associated with PRES [61], an infectious precursor may concurrently trigger both a glomerulonephritis and a cerebral vascular dysfunction [14]. Agents such as calcineurin inhibitors; sirolimus; platinum-containing cancer drugs; angiogenesis inhibitors; and, more rarely, systemic corticosteroids have also been associated with PRES [3] but none of the patients included in this review were pretreated with the mentioned agents. Very recent data argue for a central role of innate in the pathophysiology of PRES [62].

The term PRES was adopted 25 years ago [1] because neuroimaging studies detected a brain edema situated in the subcortical white matter of the occipital region. This edema pattern was noted in slightly more than half of our cases. In this study, however, we observed a diffuse edema in more than $40 \%$ of cases, as reported in the recent literature $[2,12,13]$. It has been therefore suggested to abandon the word "posterior" and use instead terms such as reversible leukoencephalopathy syndrome or acute brain capillary leak syndrome [2]. Interestingly, demographics, the clinical features, and the severity of arterial hypertension and kidney disease did not differ between patients with posterior and diffuse brain edema. Intracranial hemorrhage and ischemia may occur in a minority of patients with PRES, as confirmed by the present analysis [2]. Remarkably, two of the three patients with the aforementioned complications of PRES were affected by sickle cell anemia. Since PRES is being increasingly recognized in sickle cell anemia [63], we tentatively speculate that both acute glomerulonephritis and sickle cell anemia might have contributed to the development of PRES.

The present data do not allow us to suggest the management of PRES in acute postinfectious glomerulonephritis. However, it is assumed but not proven that early recognition and treatment are of paramount importance because PRES is usually reversible with appropriate management $[2,59$, $60,64]$. Neuroimaging is essential to the diagnosis. While a brain CT scan is sometimes the first study performed, a brain magnetic resonance imaging with an imaging protocol tailored to PRES is the critical imaging method [65].

The currently recommended mainstay of therapy is reduction of excessive blood pressure. With blood pressure 
lowered, most patients improve dramatically [64]. Goal blood pressure depends on presenting levels. Like in all cases of severe symptomatic acute hypertension, a reduction of mean blood pressure by $\leq 20-25 \%$ within $6-9 \mathrm{~h}$ is often advised $[63,64,66]$. However, excessive blood pressure lowering might reduce pressure below the autoregulatory range $[64,66]$. Reducing blood pressure is also recommended for lower levels of arterial hypertension. In these cases, a reduction by $10 \%$ within days seems a realistic target [64]. The use of easily titratable parenteral agents is effective and safe in reducing blood pressure to a desirable range. Systemic corticosteroids are sometimes prescribed in acute postinfectious glomerulonephritis and in PRES [2, 6, 7]. However, this is not generally recommended.

There are limitations and strengths that should be considered when reading the results of this review. The major limitation results from the small number of reported cases, which were sometimes not very well documented. Second, since treatment recommendations can be uneasily inferred by pooling individual cases, suggested therapy recommendations arise from low-quality evidence. Finally, a systematic review addressing all PRES cases associated with an acute glomerulonephritis syndrome including among others immunoglobulin A vasculitis, immunoglobulin A glomerulonephritis, and classic post-diarrheal hemolytic-uremic syndrome might have perhaps allowed for a more in-depth data analysis.

The most relevant strength of the study relates to the comprehensive and exhaustive literature search, which aimed at surveying the entire literature on PRES complicating acute postinfectious glomerulonephritis.

\section{Conclusion}

Unlike immunoglobulin A vasculitis, severe hypertension is the main factor underlying PRES in acute poststreptococcal postinfectious glomerulonephritis. The mechanisms underlying PRES in the absence of severe hypertension deserve future investigations.

Supplementary Information The online version contains supplementary material available at https://doi.org/10.1007/s00467-021-05244-z.

Funding Open access funding provided by Università della Svizzera italiana.

\section{Declarations}

Conflict of interest The authors declare no competing interests.

Open Access This article is licensed under a Creative Commons Attribution 4.0 International License, which permits use, sharing, adaptation, distribution and reproduction in any medium or format, as long as you give appropriate credit to the original author(s) and the source, provide a link to the Creative Commons licence, and indicate if changes were made. The images or other third party material in this article are included in the article's Creative Commons licence, unless indicated otherwise in a credit line to the material. If material is not included in the article's Creative Commons licence and your intended use is not permitted by statutory regulation or exceeds the permitted use, you will need to obtain permission directly from the copyright holder. To view a copy of this licence, visit http://creativecommons.org/licenses/by/4.0/.

\section{References}

1. Hinchey J, Chaves C, Appignani B, Breen J, Pao L, Wang A, Pessin MS, Lamy C, Mas JL, Caplan LR (1996) A reversible posterior leukoencephalopathy syndrome. N Engl J Med 334:494-500. https://doi.org/10.1056/NEJM199602223340803

2. Levitt A, Zampolin R, Burns J, Bello JA, Slasky SE (2019) Posterior reversible encephalopathy syndrome and reversible cerebral vasoconstriction syndrome: distinct clinical entities with overlapping pathophysiology. Radiol Clin North Am 57:1133-1146. https://doi.org/10.1016/j.rcl.2019.07.001

3. Milani GP, Bianchetti MG, Mazzoni MB, Triulzi F, Mauri MC, Agostoni C, Fossali EF (2014) Arterial hypertension and posterior reversible cerebral edema syndrome induced by risperidone. Pediatrics 133:e771-e774. https://doi.org/10.1542/peds. 2013-1301

4. Fux CA, Bianchetti MG, Jakob SM, Remonda L (2006) Reversible encephalopathy complicating post-streptococcal glomerulonephritis. Pediatr Infect Dis J 25:85-87. https://doi.org/10.1097/01.inf. 0000195614.66987.2f

5. Milani GP, Edefonti A, Tardini G, Arturi E, Cinnante CM, Laicini EA, Leva E, Cappellari AM, Agostoni C, Fossali EF (2014) Severe and isolated headache associated with hypertension as unique clinical presentation of posterior reversible encephalopathy syndrome. BMC Pediatr 14:190. https://doi.org/10.1186/1471-2431-14-190

6. VanDeVoorde RG 3rd (2015) Acute poststreptococcal glomerulonephritis: the most common acute glomerulonephritis. Pediatr Rev 36:3-13. https://doi.org/10.1542/pir.36-1-3

7. Hunt EAK, Somers MJG (2019) Infection-related glomerulonephritis. Pediatr Clin North Am 66:59-72. https://doi.org/10. 1016/j.pcl.2018.08.005

8. Liberati A, Altman DG, Tetzlaff J, Mulrow C, Gøtzsche PC, Ioannidis JP, Clarke M, Devereaux PJ, Kleijnen J, Moher D (2009) The PRISMA statement for reporting systematic reviews and metaanalyses of studies that evaluate health care interventions: explanation and elaboration. Ann Intern Med 151:W65-W94. https:// doi.org/10.7326/0003-4819-151-4-200908180-00136

9. Kidney Disease: Improving Global Outcomes (KDIGO) Acute Kidney Injury Work Group (2012) KDIGO clinical practice guideline for acute kidney injury. Kidney Int Suppl 2:1-138

10. Flynn JT, Kaelber DC, Baker-Smith CM, Blowey D, Carroll AE, Daniels SR, de Ferranti SD, Dionne JM, Falkner B, Flinn SK, Gidding SS, Goodwin C, Leu MG, Powers ME, Rea C, Samuels J, Simasek M, Thaker VV, Urbina EM; Subcommittee on screening and management of high blood pressure in children (2017) Clinical practice guideline for screening and management of high blood pressure in children and adolescents. Pediatrics 140:e20171904. https://doi.org/10.1542/peds.2017-1904

11. Simonetti GD, Santoro L, Ferrarini A, Crosazzo-Franscini L, Fossali E, Bianchetti MG; CHILD Project (2007) Systemic hypertension and proteinuria in childhood chronic renal parenchymal disease: role of antihypertensive drug management. Paediatr Drugs 9:413-418. https://doi.org/10.2165/00148581-200709060-00008 
12. Li Y, Gor D, Walicki D, Jenny D, Jones D, Barbour P, Castaldo J (2012) Spectrum and potential pathogenesis of reversible posterior leukoencephalopathy syndrome. J Stroke Cerebrovasc Dis 21:873-882. https://doi.org/10.1016/j.jstrokecerebrovasdis.2011. 05.010

13. Brady E, Parikh NS, Navi BB, Gupta A, Schweitzer AD (2018) The imaging spectrum of posterior reversible encephalopathy syndrome: a pictorial review. Clin Imaging 47:80-89. https://doi.org/ 10.1016/j.clinimag.2017.08.008

14. Kaplan RA, Zwick DL, Hellerstein S, Warady BA, Alon U (1993) Cerebral vasculitis in acute post-streptococcal glomerulonephritis. Pediatr Nephrol 7:194-195. https://doi.org/10.1007/BF008 64396

15. Saatçi I, Topaloğlu R (1994) Cranial computed tomographic findings in a patient with hypertensive encephalopathy in acute poststreptococcal glomerulonephritis. Turk J Pediatr 36:325-328

16. Nordby JA (1997) Neurological presentation of poststreptococcal glomerulonephritis. Clin Pediatr (Phila) 36:105-108. https://doi. org/10.1177/000992289703600207

17. Rovang RD, Zawada ET Jr, Santella RN, Jaqua RA, Boice JL, Welter RL (1997) Cerebral vasculitis associated with acute poststreptococcal glomerulonephritis. Am J Nephrol 17:89-92. https:// doi.org/10.1159/000169077

18. Froehlich T, Sandifer S, Varma PK, Testa FM (1999) Two cases of hypertension-induced reversible posterior leukoencephalopathy syndrome secondary to glomerulonephritis. Curr Opin Pediatr 11:512-518. https://doi.org/10.1097/00008480-199912000-00007

19. Soylu A, Kavukçu S, Türkmen M, Akbaş Y (2001) Posterior leukoencephalopathy syndrome in poststreptococcal acute glomerulonephritis. Pediatr Nephrol 16:601-603. https://doi.org/10.1007/s004670100601

20. Caramés Bartolomé E, Rodrigues Sousa C, Morais Barbosa C (2002) Leucoencefalopatía posterior reversible secundaria a glomerulonephritis [Reversible posterior leukoencephalopathy secondary to glomerulonephritis]. An Esp Pediatr 56:474-476

21. Casali-Rey JI, Dávalos EG, López-Amalfara A, Julio-Muñoz D, Pagano MA (2003) Sindrome de encefalopatía posterior reversible: presentación de casos clínicos [Posterior reversible encephalopathy syndrome: some case reports]. Rev Neurol 37:224-227

22. Yang MH, Sheu JN, Wang SJ (2003) Cortical blindness in a boy with acute glomerulonephritis. J Formos Med Assoc 102:52-54

23. Özçakar ZB, Ekim M, Fitoz S, Teber S, Hizel S, Acar B, Yüksel $S$, Yalcinkaya F (2004) Hypertension induced reversible posterior leukoencephalopathy syndrome: a report of two cases. Eur J Pediatr 163:728-730. https://doi.org/10.1007/s00431-004-1532-8

24. Bazzino F, Pandolfo S, Protasio L, Pujadas M, Cerisola A, González G, Caggiani M, Rubio I (2005) Leucoencefalopatía posterior reversible secundaria a glomerulonefritis postestreptocócica: a propósito de un caso [Posterior reversible leukoencephalopathy syndrome associated with poststreptococcal postinfectious glomerulonephritis: case report]. Arch Pediatr Urug 76:228-233

25. Lizarazo J, Tibasosa D, Alandete S (2005) Síndrome de encefalopatía posterior reversible [Posterior reversible encephalopathy syndrome]. Acta Neurol Colomb 21:289-298

26. Ohtomo Y, Takada M, Fujinaga S, Murakami H, Yamashiro Y (2005) Hypertensive encephalopathy in a boy with biopsy-proven acute post-streptococcal glomerulonephritis. Pediatr Int 47:323325. https://doi.org/10.1111/j.1442-200x.2005.02071.x

27. Aeby A, David P, Fricx C, Jissendi P, Blecic S, Van Bogaert P (2005) Posterior reversible encephalopathy syndrome revealing acute post-streptococcal glomerulonephritis. J Child Neurol 21:250-251. https://doi.org/10.2310/7010.2006.00057

28. Ishikura K, Ikeda M, Hamasaki Y, Hataya H, Shishido S, Asanuma H, Nishimura G, Hiramoto R, Honda M (2006) Posterior reversible encephalopathy syndrome in children: its high prevalence and more extensive imaging findings. Am J Kidney Dis 8:231-238. https://doi.org/10.1053/j.ajkd.2006.04.076
29. Ritt M, Campean V, Amann K, Heider A, Griesbach D, Veelken R (2006) Transient encephalopathy complicating poststreptococcal glomerulonephritis in an adult with diagnostic findings consistent with cerebral vasculitis. Am J Kidney Dis 48:489-494. https://doi. org/10.1053/j.ajkd.2006.06.004

30. Ram R, Swarnalatha G, Prasad N, Dakshinamurty KV (2007) Glomerulonephritis and altered mental status. Kidney Int 72:14131414. https://doi.org/10.1038/sj.ki.5002542

31. Wirrell EC, Hamiwka LD, Hamiwka LA, Grisaru S, Wei X (2007) Acute glomerulonephritis presenting with PRES: a report of 4 cases. Can J Neurol Sci 34:316-321. https://doi.org/10.1017/ s0317167100006740

32. Dursun I, Gunduz Z, Poyrazoglu HM, Gumus H, Yikilmaz A, Dusunsel R (2008) Cerebral vasculitis and unilateral sixth-nerve palsy in acute post-streptococcal glomerulonephritis. Ann Trop Paediatr 28:155-159. https://doi.org/10.1179/146532808X302198

33. Pashankar FD, Ment LR, Pearson HA (2008) Sickle cell disease complicated by post-streptococcal glomerulonephritis, cerebral hemorrhage and reversible posterior leucoencephalopathy syndrome. Pediatr Blood Cancer 50:864-866. https://doi.org/10.1002/ pbc. 21321

34. Bekmezian A, Lasky JL 3rd, Osman S, Kaddurah AK, Varela AM, Velez K, Alvarez O (2009) Index of suspicion. Pediatr Rev 30:311-316. https://doi.org/10.1542/pir.30-8-311

35. Gupta S, Goyal VK, Talukdar B (2010) Reversible posterior leucoencephalopathy syndrome in post streptococcal glomerulonephritis. Indian Pediatr 47:274-276. https://doi.org/10.1007/ s13312-010-0037-y

36. Gümüş H, Per H, Kumandaş S, Yikilmaz A (2010) Reversible posterior leukoencephalopathy syndrome in childhood: report of nine cases and review of the literature. Neurol Sci 31:125-131. https://doi.org/10.1007/s10072-009-0158-z

37. Psychogios MN, Schramm P, Knauth M (2010) Reversibles Enzephalopathie-Syndrom, RES oder PRES: ein Fall mit mehr W (watershed) als P (posterior)! [Reversible encephalopathy syndrome, RES or PRES: a case with more W (watershed) than P (posterior)!]. Röfo 182:76-79. https://doi.org/10.1055/s-00281109778

38. Berdai AM, Harandou M (2012) Une encéphalopathie postérieure réversible révélant une glomérulonéphrite post infectieuse [A posterior reversible encephalopathy revealing post infectious glomerulonephritis]. Pan Afr Med J 13:82

39. Endo A, Fuchigami T, Hasegawa M, Hashimoto K, Fujita Y, Inamo Y, Mugishima H (2012) Posterior reversible encephalopathy syndrome in childhood: report of four cases and review of the literature. Pediatr Emerg Care 28:153-157. https://doi. org/10.1097/PEC.0b013e3182442fe8

40. Grimminck B, de Jong H, Sluzewski M, Obihara CC (2012) Een kind met onbegrepen convulsies: posterieur reversibel encefalopathiesyndroom [A child with convulsions of unknown origin: posterior reversible encephalopathy syndrome]. Ned Tijdschr Geneeskd 156:A3920

41. Kaarthigeyan K, Vijayalakshmi AM (2012) Cortical blindness in a child with acute glomerulonephritis. Indian J Nephrol 22:42-44. https://doi.org/10.4103/0971-4065.86408

42. Ortiz A, Elsässer S, Roverano S, Paira S (2012) Síndrome de encefalopatía posterior reversible (PRES): comunicación de tres casos [Posterior reversible encephalopathy syndrome: a report of three cases]. Rev Argent Reumatol 23:52-60

43. Alves GRT, Cordenonsi ICO, Silva RVA, Haygert CJP (2013) Posterior reversible encephalopathy syndrome following poststreptococcal glomerulonephritis. Banglad J Med Sci 12:341343. https://doi.org/10.3329/bjms.v12i3.13323

44. Dasgupta MK, Sarkar S, Patra C (2013) Posterior reversible encephalopathy syndrome in a case of post-streptococcal glomerulonephritis. J Pediatr Sci 5:e1192 
45. Sfaihi L, Kamoun F, Hentati Y, Tiss O, Maaloul I, Kamoun T, Mnif Z, Hachicha M (2013) Syndrome d'encéphalopathie postérieure réversible induit par une glomérulonéphrite aiguë postinfectieuse [Posterior reversible encephalopathy syndrome induced by acute postinfectious glomerulonephritis]. Arch Pédiatr 20:633-636. https://doi.org/10.1016/j.arcped.2013.03.014

46. Adikari M, Priyangika D, Marasingha I, Thamotheram S, Premawansa G (2014) Post-streptococcal glomerulonephritis leading to posterior reversible encephalopathy syndrome: a case report. BMC Res Notes 7:644. https://doi.org/10.1186/ 1756-0500-7-644

47. Akın F, Kılıçaslan C, Solak ES, Uzun M, Aygün S, Arslan Ş (2014) Posterior reversible encephalopathy syndrome in children: report of three cases. Childs Nerv Syst 30:535-540. https://doi. org/10.1007/s00381-013-2342-y

48. Kasap B, Çarman KB, Yiş U (2014) A case of acute post-streptococcal glomerulonephritis that developed posterior reversible encephalopathy syndrome. Turk Pediatri Ars 49:348-352. https:// doi.org/10.5152/tpa.2014.430

49. Kumar SR, Kumar M, Shobhana S, Sampath S, Kasthuri RK (2014) Posterior reversible encephalopathy syndrome unmasking acute glomerulonephritis. J Clin Diagn Res 8:177-178. https:// doi.org/10.7860/JCDR/2014/6465.3818

50. Zaki SA, Shanbag P (2014) Unusual presentation of poststreptococcal glomerulonephritis as posterior reversible encephalopathy syndrome. J Pediatr Neurosci 9:42-44. https://doi.org/10.4103/ 1817-1745.131484

51. Abdool K, Ramcharan K, Bhagwandass N, Persad N, Temull V, Seegobin K, Mike C (2015) Posterior reversible encephalopathy syndrome and acute post-streptococcal glomerulonephritis mimicking breakthrough seizures. Neurol Int 7:5971. https://doi.org/ 10.4081/ni.2015.5971

52. Balasubramaniyan S, Selvamuthukumaran S, Krishnamoorthy K (2015) Posterior reversible encephalopathy syndrome in post-streptococcal glomerulonephritis. J Assoc Physicians India 63:71-73

53. Tuoni C, Vierucci F, Cesaretti G, Saggese G (2015) Poststreptococcal acute glomerulonephritis presenting as posterior reversible encephalopathy syndrome in an eleven-year-old boy. Minerva Pediatr 67:531-533

54. Kostopoulou E, Bertzouanis A, Charalampous E, Varvarigou A (2017) Posterior reversible encephalopathy syndrome (PRES) presenting with status epilepticus in the context of post-streptococcal glomerulonephritis. J Infect Dis Med 2:107. https://doi.org/10. 4172/2576-1420.1000107

55. Reyes HA, Witsch J, Sueldo C, Hong J (2017) Posterior reversible encephalopathy in an adult patient with poststreptococcal glomerulonephritis. BMJ Case Rep 2017:bcr2017220043. https://doi. org/10.1136/bcr-2017-220043

56. Hanafy E, Alshareef D, Osman S, Al Jabri A, Nazim F, Mahmoud G (2018) Posterior reversible encephalopathy syndrome secondary to asymptomatic poststreptococcal glomerulonephritis in a child with sickle cell anemia: a case report. J Med Case Rep 12:24. https://doi.org/10.1186/s13256-017-1559-x

57. Rasheed J, Hassan R, Zafar F (2018) Posterior reversible encephalopathy syndrome secondary to acute poststreptococcal glomerulonephritis in a 12-year-old girl. J Coll Physicians Surg Pak 28:80-81. https://doi.org/10.29271/jcpsp.2018.01.80

58. Doğan CS, Aksoy GK, Kutluk MG, Özkan MB (2020) Posterior reversible encephalopathy syndrome in an adolescent with acute poststreptococcal glomerulonephritis. J Pediatr Neurol 18:144147. https://doi.org/10.1055/s-0039-1683999

59. Miller JB, Suchdev K, Jayaprakash N, Hrabec D, Sood A, Sharma S, Levy PD (2018) New developments in hypertensive encephalopathy. Curr Hypertens Rep 20:13. https://doi.org/10.1007/ s11906-018-0813-y

60. August $P$ (2016) Hypertensive encephalopathy: what's in a name? J Am Soc Hypertens 10:404-405. https://doi.org/10.1016/j.jash. 2016.03.189

61. Lava SAG, Peeters GG, Bianchetti MG, Goeggel Simonetti B, Simonetti GD, Milani GP (2017) Posterior reversible encephalopathy syndrome in Henoch-Schönlein purpura. Rheumatol Int 37:461-463. https://doi.org/10.1007/s00296-016-3577-1

62. Nelke C, Schulte-Mecklenbeck A, Pawlitzki M, Rolfes L, Räuber S, Gross CC, Minnerup J, Meuth SG, Wiendl H, Ruck T (2021) The innate immune response characterizes posterior reversible syndrome. J Clin Immunol. https://doi.org/10.1007/ s10875-021-01033-3

63. Solh Z, Taccone MS, Marin S, Athale U, Breakey VR (2016) Neurological PRESentations in sickle cell patients are not always stroke: a review of posterior reversible encephalopathy syndrome in sickle cell disease. Pediatr Blood Cancer 63:983-989. https:// doi.org/10.1002/pbc. 25932

64. Seeman T, Hamdani G, Mitsnefes M (2019) Hypertensive crisis in children and adolescents. Pediatr Nephrol 34:2523-2537. https:// doi.org/10.1007/s00467-018-4092-2

65. Bartynski WS, Boardman JF (2007) Distinct imaging patterns and lesion distribution in posterior reversible encephalopathy syndrome. Am J Neuroradiol 28:1320-1327. https://doi.org/10.3174/ ajnr.A0549

66. Calvetta A, Martino S, von Vigier RO, Schmidtko J, Fossali E, Bianchetti MG (2003) "What goes up must immediately come down!" Which indication for short-acting nifedipine in children with arterial hypertension? Pediatr Nephrol 18:1-2. https://doi. org/10.1007/s00467-002-1010-3

Publisher's note Springer Nature remains neutral with regard to jurisdictional claims in published maps and institutional affiliations. 